\title{
TOTAL FLAVONOID DAN AKTIVITAS PENANGKAPAN RADIKAL BEBAS DARI EKSTRAK ETANOLIK DAUN DAN BUAH MENGKUDU
}

\section{TOTAL FLAVONOID AND FREE RADICAL SCAVENGING ACTIVITY OF ETHANOLIC EXTRACT OF MORINDA CITRIFOLIA L. LEAVES AND FRUITS}

\author{
1)Dyan Wigati, 2)Dwi Koko Pratoko \\ dyanwigati@gmail.com \\ ${ }^{1}$ Laboratorium Biologi Farmasi, Farmasi, Sekolah Tinggi Ilmu Farmasi "Yayasan Pharmasi Semarang", Semarang \\ ¿Laboratorium Sintesis dan Kimia Medisinal, Fakultas Farmasi, Universitas Jember, Jember
}

\begin{abstract}
Intisari
Morinda citrifolia L. adalah tanaman yang umum digunakan dalam pengobatan tradisional dan mengandung banyak flavonoid. Tujuan dari penelitian ini adalah untuk mengukur kadar flavonoid total dan aktivitas penangkapan radikal bebas dari ekstrak etanolik daun dan buah mengkudu sebagai sumber antioksidan. Flavonoid total diukur dengan metode kolorimetri menggunakan alumunium klorida. Aktivitas antioksidan dari ekstrak etanolik daun dan buah mengkudu diukur dengan metode DPPH. Kadar lavonoid total dari ekstrak daun (23.05 $\pm 0.77 \mathrm{mg} \mathrm{RE} / \mathrm{g}$ ) lebih tinggi dari ekstrak buah $(18.81 \pm 1.10 \mathrm{mg} \mathrm{RE} / \mathrm{g})$. Aktivitas penangkapan radikal bebas ditunjukkan dengan nilai IC 50 dari ekstrak daun (49.09 $\pm 0.40 \mu \mathrm{g} / \mathrm{mL}$ ) lebih tinggi dari ekstrak buah $(384.08 \pm 2.29 \mu \mathrm{g} / \mathrm{mL})$. Uji t-test menunjukkan bahwa ada perbedaan signifikan antara ekstark daun dan ekstrak buah $(p<0.05)$ baik dari nilai flavonoid total maupun aktivitas antioksidan. Dari data tersebut menunjukkan bahwa baik daun dan buah mengkudu memiliki kemampuan dalam menghambat aktivitas radikal bebas.
\end{abstract}

Kata kunci :Morinda citrifolia L., DPPH, total flavonoid, Antioksidan

\begin{abstract}
Morinda citrifolia $L$. is a plant widely used as a traditional medicine that rich of flavonoid contents. The aims of this study were to determined the total flavonoid content and free radical scavenging activity ethanolic extract of M. citrifolia L. leaves and fruits in order to find a new antioxidant sources. Total flavonoid contents were determined by aluminium chloride colorimetric method. The free radical scavenging activity of the extract ethanolic of $M$. citrifolia L. leaves and fruits were measured in vitro by 2,2-diphenyl-1-picrylhadrazyl (DPPH) assay. The total flavonoid contents of $M$. citrifolia L. leaves extract (23.05 $\pm 0.77 \mathrm{mg} R E / g$ extract) were found significantly higher than fruits extract $(18.81 \pm 1.10 \mathrm{mg} R E / g$ extract). Free radical scavenging activity of ethanolic extract of M. citrifolia L. leaves and fruits show that IC50 values of the leaves extract $(49.09 \pm 0.40 \mu \mathrm{g} / \mathrm{mL})$ higher than IC50 values of the fruits extract $(384.08 \pm 2.29 \mu \mathrm{g} / \mathrm{mL})$. The $t$-test result show a significant difference between fruits extract and leaves extract of the total flavonoid and free radical scavenging activity ( $p$ $<0,05)$. Data from present result revealed that both of $M$. citrifolia $L$. leaves and fruits extract act as an antioxidant agent due to its free radical scavenging activity.
\end{abstract}

Keywords : Morinda citrifolia, DPPH, total flavonoid, Antioxidant 


\section{Pendahuluan}

Mengkudu (Morinda citrifolia L.) dari familia Rubiaceae, umumnya dikenal dengan nama noni meupakan tanaman yang banyak digunakan sebagai obat tradisional dalam mengobati diabetes, tekanan darah tinggi, kanker, masalah mata dan meringankan gejala alergi seperti bronkitis, asma dan pruritis (Praveen dkk, 2007). Popularitas dari mengkudu sebagai suplemen obat atau suplemen untuk meningkatkan kesehatan semakin meningkat di seluruh dunia. Mengkudu telah digunakan untuk menyembuhkan berbagai gejala penyakit, seperti antihipertensi, hipoglikemik, dan anti-demensia. Daun, buah, akar, batang, kulit kayu dan bunga dari mengkudu banyak digunakan dalam berbagai kombinasi pengobatan herbal. Lebih dari seratus senyawa nutraceutical telah diidentifikasi dari tanaman mengkudu. Mengkudu memiliki potensi sebagai sumber antioksidan alami (antioksidan fitokimia). Sang dkk. (2001) melaporkan bahwa daun mengkudu mengandung flavonoid seperti rutin dan quercetin. Seperti telah diketahui kandungan flavonoid, betakaroten, terpenoid, asam askorbat, tokoferol adalah beberapa antioksidan yang dihasilkan oleh tanaman (Ying dkk, 2002) .

Flavonoid merupakan salah satu metabolit sekunder yang dapat ditemukan dalam berbagai buahbuahan, sayuran dan rempah-rempah. Beberapa penelitian melaporkan bahwa flavonoid dapat melindungi lipid membran (Hossain dkk, 2006) dan melawan stres oksidatif dari oksidator dan radikal bebas. Pembentukan radikal bebas berhubungan dengan metabolisme alami normal sel aerobik dan konsumsi oksigen yang melekat dalam pertumbuhan sel (Antolovich dkk, 2000; Matkowski, 2006; Sarikurkcu dkk, 2009). Tujuan dari penelitian ini adalah untuk menentukan kandungan flavonoid total dan untuk mengevaluasi aktivitas antioksidan dari ekstrak etanol daun dan buah mengkudu (Morinda citrifoliaL.).

\section{Metode Penelitian}

\section{Alat}

Spektofotometer UV-Vis U1800 (Shimadzu), rotary evaporator, alat gelas.

\section{Bahan}

Pucuk daun mengkudu dan buah mengkudu yang sudah masak diperoleh dari daerah Sendangguwo, dipanen pada sore hari. Etanol 96\% pa (merck), metanol pa (merck), aquadest, 2,2'-diphenyl-1picrylhadrazyl (DPPH), rutin (Sigma aldrich), $\mathrm{AlCl}_{3}$, $\mathrm{NaNO}_{2}, \mathrm{NaOH}$

\section{Tahap penelitian}

1. Penyiapan ekstrak

Daun dan buah mengkudu kering (1 $\mathrm{kg})$ diekstraksi dengan metode remaserasi selama 3 hari dengan etanol $96 \%$ (1:10) pada suhu ruang dan dengan pengadukan yang berkesinambungan. Maserat yang dihasilkan diuapkan dengan rotary evaporator dibawah suhu $40{ }^{\circ} \mathrm{C}$ hingga diperoleh ekstrak kental daun dan buah mengkudu.

2. Pengukuran kadar flavonoid total

Pengukuran kadar flavonoid total menggunakan metode kolorimetri menggunakan $\mathrm{AlCl}_{3}$. Sebanyak75 mg sampel ekstrak daun dan buah mengkudu masing masing ditambahkan $5 \mathrm{ml}$ aquadest dan $0,3 \mathrm{ml} \mathrm{NaNO} 25 \%$. Setelah 6 menit 0,3 ml AlCl3 ditambahkan ke dalam campuran tersebut diamkan kembali selama 6 menit kemudian tambahkan $4 \mathrm{ml}$ $\mathrm{NaOH} 4 \%$ dan aquadest sampai volume 25, $0 \mathrm{ml}$. Absorbansi diukur dengan menggunakan spetrofotometer UV-Vis dengan panjang gelombang $507 \mathrm{~nm}$. Flavonoid total dihitung ekivalen dengan rutin (RE)/gram sampel. Dilakukan 3 kali replikasi.

\section{Aktivitas peredaman radikal DPPH}

Aktivitas antioksidan dari ekstrak etanolik. daun dan buah mengkudu diukur dengan menggunakan 2,2-difenil-1-picrylhadrazyl. (DPPH). Sebanyak $0,3 \mathrm{ml}$ ekstrak sampel dan larutan asam askorbat dimasukkan ke dalam tabung reaksi yang berbeda dan ditambahkan 1,2 $\mathrm{ml}$ 0,1 $\mathrm{mM}$ DPPH. Campuran reaksi tersebut disimpan di tempat gelap pada suhu $37{ }^{0} \mathrm{C}$ selama 30 menit. Kontrol dibuat dengan mencampur $0,3 \mathrm{ml}$ metanol dengan $1,2 \mathrm{ml} \mathrm{0,1}$ $\mathrm{mM}$ DPPH. Absorbansi menggunakan spektrofotometer UV-vis pada panjang gelombang $515 \mathrm{~nm}$. Pengukuran dilakukan dalam 3 kali replikasi. Besarnya aktivitas antioksidan dihitung menggunakan rumus berikut :

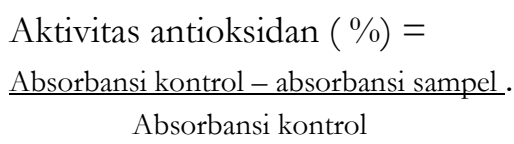

Konsentrasi sampel yang yang diperlukan untuk menangkap $50 \%$ radikal DPPH dinyatakan sebagai konsentrasi hambatan 50\% (IC50). 


\section{Analisis data}

Hasil pengukuran flavonoid total dan aktivitas antioksidan diuji T-test dengan nilai signifikasi $(\mathrm{p}<0,05)$

\section{Hasil dan Pembahasan}

Mengkudu adalah salah satu tanaman yang banyak dimanfaatkan sebagai obat tradisional untuk berbagai penyakit seperti sebagai antioksidan, menghambat ACE, analgesik, antiinflamasi dan antimikroba (Yamaguchi dkk, 2004; Kamiya dkk, 2008; Basar dkk, 2010; West dkk, 2011). Bagian tanaman yang sering digunakan adalah buahnya baik direbus, diperas, dimakan secara langsung maupun difermentasi sehingga menjadi bentuk sediaan jus. Daun mengkudu banyak mengandung flavonoid antara lain rutin, kuersetin yang memiliki kemampuan sebagai antioksidan alami.

Beberapa penelitian menunjukkan bahwa flavonoid memiliki kemampuan mereduksi pembentukan radikal bebas dan mencegah stress oksidatif. Radikal bebas adalah kelompok senyawa kimia yang bersifat sangat reaktif karena memiliki satu atau lebih elektron bebas yang tidak stabil dan dapat menyebabkan kerusakan sel, mengganggu fungsi sel atau bahkan kematian sel.Metode yang digunakan untuk mengukur kadar flavonoid total adalah kolorimetri menggunakan $\mathrm{AlCl}_{3} . \mathrm{AlCl}_{3}$ akan membentuk ikatan komplek dengan grup hidroksil dari struktur flavonoid dan absorbansinya diamati dengan menggunakan spektrofotometer UV-vis.

Pada penelitian ini nilai flavonoid total dari ekstrak daun dan ekstrak buah, berturut-turut 23,05 \pm $0,77 \mathrm{dan} 18,81 \pm 1,10 \mathrm{mg}$ rutin ekivalen/g(RE/g) sampel seperti yang ditunjukkan pada tabel 1 . Hasil pengukuran menunjukkan bahwa kandungan flavonoid total dari ekstrak daun lebih tinggi dari ekstrak buah mengkudu. Hal ini sejalan dengan penelitian Wigati dkk (2016) yang melaporkan bahwa kadar fenol total dari ekstrak daun mengkudu juga lebih tinggi dari ekstrak buah mengkudu. Tingginya kandungan flavonoid total dan kadar fenol total pada daun mengkudu dibandingkan buah mengkudu menunjukkan bahwa pada tiap bagian dari tanaman memiliki kandungan metabolit sekunder yang berbeda.

Aktivitas antioksidan pada penelitian ini menggunakan metode peredaman DPPH. DPPH secara umum digunakan untuk mengukur kemampuan senyawa dalam menghambat radikal bebas. Kelebihan metode DPPH ini adalah cepat, sederhana, akurat dan murah (Marinova \& Batchvarov, 2011). Metode ini didasarkan pada kemampuan senyawa uji dalam mendonorkan elektron atau atom hidrogen yang akan bereaksi dengan radikal bebas DPPH. Interaksi radikal bebas DPPH (2,2'-diphenyl-1-picrylhadrazyl) dengan antioksidan akan mengubahnya menjadi 2,2'diphenyl-1-picrylhydrazine dan mengalami perubahan warna (ungu menjadi kuning). Aktivitas antioksidan dari sampel ekstrak daun dan buah mengkudu yang mengandung senyawa fenolik seperti flavonoid juga menyebabkan perubahan warna pada larutan sehingga dapat dikatakan senyawa fenolik dalam ekstrak daun dan buah mengkudu tersebut berpotensi sebagai antioksidan alami. Tingkat perubahan warna sebanding dengan konsentrasi dan kapasitasnya sebagai antioksidan (Heinonen dkk, 1998) serta struktur komponen senyawa penangkap radikal bebas (Naik dkk, 2003).

Hasil penentuan aktivitas antioksidan didapatkan bahwa seiring peningkatan konsentrasi dari ekstrak buah dan daun, terjadi peningkatan persen peredaman dari DPPH (gambar 1). Melalui perhitungan analisis probit, didapatkan nilai $\mathrm{IC}_{50}$ dari ekstrak daun dan buah mengkudu berturut-turut $49,09 \pm 0,40 \mu \mathrm{g} / \mathrm{mL}$ dan 384,08 $\pm 2,29 \mu \mathrm{g} / \mathrm{mL}$ (tabel 1). Hasil pengujian menunjukkan bahwa ekstrak buah mengkudu memiliki aktivitas antioksidan yang lemah karena nilai $\mathrm{IC}_{50}>150 \mu \mathrm{g} / \mathrm{mL}$, sedangkan ekstrak daun mengkudu memiliki aktivitas antioksidan sangat kuat $<50 \mu \mathrm{g} / \mathrm{mL}$. Hal ini senada dengan penelitian Zindkk (2002) yang melaporkan bahwa kandungan antioksidan dari beberapa bagian tanaman mengkudu menunjukkan perbedaan yang signifikan. Aktivitas antioksidan pada ekstrak daun mengkudu yang lebih tinggi diandingkan aktivitas antioksidan pada buah mengkudu sejalan dengan kandungan fenolik total dan flavonoid total dari ekstrak keduanya. Semakin tinggi kandungan fenolik total dan flavonoid total, maka nilai IC50 akan semakin rendah, sehingga aktivitas antioksidannya akan semakin tinggi.

Tingginya aktivitas antioksidan pada daun mengkudu salah satunya disebabkan oleh kandungan flavonoid daun mengkudu lebih tinggi dibandingkan buah mengkudu. Sang dkk. (2001) melaporkan bahwa daun mengkudu kaya flavonoid seperti rutin dan 
quercetin. Mekanisme flavonoid quercetin sebagai antioksidan dijelaskan oleh Rice-Evans.Struktur quercetin dan rutin (quercetin-3-O-rutinosida) menunjukkan peran penting dalam menentukan potensi antioksidan flavonoid (gambar 2). cincin B yang ter-dihidroksilasi memainkan peran paling penting dalam menyumbangkan hidrogen (elektron) untuk menstabilkan senyawa radikal. Adanya gugus 2,3-takjenuh yang terkonjugasi pada 4-oxo pada cincin C, mampu mengikat ion logam transisi (Fe dan $\mathrm{Cu}$ (Rice-Evans, 1996).

Hasil penelitian ini menunjukkan bahwa senyawa fenolik seperti flavonoid (quercetin dan rutin) mempunyai peran utama sebagai antioksidan dari ekstrak daun dan buah mengkudu. Senyawa fitokimia ini mampu menyumbangkan elektron (hidrogen) pada radikal bebas untuk menangkal kerusakan yang potensial (Hossain \& Shah, 2015; Gilani dkk, 2010).

Hasil ini juga berkorelasi dengan penelitian lainnya, yang menunjukkan bahwa tanaman berdaun hijau memiliki kapasitas antioksidan tertinggi, diikuti oleh buah-buahan dan tanaman akar.

\section{Simpulan}

Hasil penelitian menunjukkan bahwa ekstrak daun mengkudu memiliki kadar flavonoid total yang lebih tinggi dibandingkan dengan ekstrak buah mengkudu dan sesuai dengan aktivitas antioksidan dari ekstrak daun yang lebih kuat dibandingkan dengan buah. Hasil tersebut memberikan korelasi dengan peneliti lainnya, yang menunjukkan bahwa tanaman berdaun hijau memiliki kapasitas sebagai antioksidan tertinggi, diikuti oleh bagian buah dan akar tetapi mekanisme antioksidan tidak dapat dijelaskan hanya dengan dari adanya fenolik atau flavonoid [18].

\section{Ucapan Terimakasih}

Peneliti menyampaikan terima kasih kepada STIFAR "Yayasan Pharmasi” Semarang dan Fakultas Farmasi Universitas Jember, yang telah memberikan kesempatan untuk melakukan penelitian di laboratorium instansi tersebut di atas.

\section{Daftar Pustaka}

Antolovich, M., Prenzler, P., Robards, K., Ryan, D., 2000. Sample preparation in the analysis of phenolic compounds in fruits. Analyst, 125, 989-1009.

Basar, S, Uhlenhut, K, Hogger, P, 2010. Analgesic and antiinflammatory Activity of Morinda citrifolia L. (noni). Fruits. Phytother Res. 24, 38-42.

Gilani AH, Mandukhail SR, Iqbal J, Yasinzai M, Aziz N, Khan A, Rehman N.,2010. Antispasmodic and vasodilator activities of Morinda citrifolia root extract are mediated through blockade of voltage dependent calcium channels. $B M C$ Complement Altern Med. 10, 2.

Heinonen, M., Lehtonen, P.J., Hopla, A, 1998. Antioxidant activity of berry and fruit wines and liquor. Journal of Agricultural Food Chemistry $48,25-31$.

Hossain M.S and Shah D.M.,2015. A study on the total phenols content and antioxidant activity of essential oil and different solvent extracts of endemic plant Merremia borneensis. Arabian Journal of chemistry. Vol 8(1), 66 - 71.

Hossain, MA., Salehuddin, SM., Ismail, Z., 2006. Rosmarinic acid and methyl rosmarinate from Orthosiphon stamineus. Benth. J Bang Acad Scis. 30(2), 167-171.

Kamiya K, Hamabe W, Harada S., 2008. Chemical constituent of Morinda citrifolia roots exhibit hypoglycemic effects in streptozotuzininduced diabetic mice. Biol Pharm Bull. 31,935-938.

Lako, J., Trenerry,V.C., Wahlqvist, M., Wattana penpaiboon, N., Sotheeswaran, S., Premie, R., 2007. Phytochemical falvonols, carotenoids and the antioxidant properties of a wide selection of Fijian fruit, vegetables and other readily available foods. Food Chemistry. Vol 101(4), 1727-1741

Marinova, G and Batchvarov, V, 2011. Evaluation of the methods for determination of the free radical scavenging activity by DPPH. Bulgarian Journal of Agriculture Science,17 (1), 11-24

Matkowski, A.,2006. Plant phenolic metabolites as antioxidants and antimutagens. In: Blume, Y., Smertenko, P., Durzan, D.J. (Eds.), . In: NATO Life Science Monographs, vol. 376. IOS Press, Amsterdam, halaman. 129-148.

Naik, G.H., Priyadarsini, K.I., Satav, J.G.,Banavalikar, M.M., Sohoni, D.P., Biyani,M.K., and Mohan 
H., 2003, Comparativeantioxidant activity of individual herbal components used in ayurvedic medicine,Phytochemistry, 63 (1): 97-104

Praveen, K., Ramamoorthy, Bono, A., 2007. Antioxidant activity, Total Phenolic and Flavonoid Content of Morinda citrifolia Fruit Extracts From Various Extraction Processes. Journal of Engineering Science and Technology. 2(1), $70-80$

Rice-Evans, C. A., Miller, N. J., Paganga, G, 1996. Structure antioxidant avtivity relationship of flavonoids and phenolic acids. Free Radic. Biol. Med. 335, 166-180

Sang S, Cheng X, Zhu N, Stark RE, Badmaev V, Ghai G, Rosen R, Ho CT., 2001. Flavonol glycosides and novel iridoid glycoside from the leaves of Morinda citrifolia. J. Agric. Food Chem. 49, 4478-4481

Sarikurkcu, C., Arisoy, K., Tepe, B., Cakir, A., Abali, G., Mete, E, 2009. Studies on the antioxidant activity of essential oil and different solvent extracts of Vitex agnus castus L. Fruits from Turkey. Food and Chemical Toxicology,47 (10), 2479-2483
West, BJ, Jensen, CJ, Palu, AK., 2011. Toxicity and antioxidant test of Morinda citrifolia (noni) seed extract. Adv J Food Sci Technol. 3, 303307.

Wigati, D., Anwar, K., Sudarsono, Nugroho, A. E., 2016. Hypotensive activity of ethanolic extracts of Morinda citrifolia L. leaves and fruits in dexamethasone-induced hypertensive rat. J. Evid Based Complementary Altern Med. (epub).

Yamaguchi S, Ohnishi J, Sogawa M. 2004. Inhibition of Angiotensin I Converting Enzyme by noni (Morinda citrifolia) juice. Nippon Shokubin Kagaku Kogaku Kaishi. 49, 624-627.

Ying, W. M., West, B. J., Jensen, C. J., Nowicki, D., Chen, S., Palu, A. K., Anderson, G., 2002. Morinda citrifolia (noni) : a literature review and recent advances in noni research. Acta pharmacology. 23, 1127 - 1141

Zin, Z.M., Hamid, A.A., dan Osman, A., 2002. Antioxidative activity of Extracts from Mengkudu (Morinda citrifolia L.) Root, Fruit and Leaf. Journal of Food Chemistry, 78, 227231. 
Total flavonoid and free radical scavenging activity of ethanolic extract of morinda citrifolia l. leaves and fruits 